\title{
Transformation of Thionin Genes Using Chitosan Nanoparticle into Potato Plant to Be Resistant to Fungal Infection
}

\author{
A.B. Abdel-Razik ${ }^{1}$, I.A. Hammad², E. Tawfik ${ }^{2}$ \\ ${ }^{1}$ Genetic Department, Faculty of Agriculture, Ain Shams University \\ ${ }^{2}$ Botany and Microbiology Department, Faculty of Science, Helwan University
}

\begin{abstract}
Two thionin genes were isolated from Arabidopsis thaliana (AT1G12660 and AT1G12663). The resulted thionin protein has antifungal activity against potato pathogenic fungi like Alternaria alternata and Rhizoctonia solani. These two thionin genes were respectively inserted in $p E G A D$ vector. After that carried into chitosan nanoparticle in order to be transformed into the two tested potato cultivars (lady and spunta) using intermodal cutting technique of tissue culture. Expressions of thionin transgenes in the transgenic plants were confirmed by RT-PCR. There were two assays were applied to test the role of thionins (in the transgenic potatoes) in resistance to the pathogenic fungi: effect of spore suspension on potato organs and the inhibitory effect of thionin proteins on spore germination. As the transgenic potato plant possesses active defense systems and can protect themselves from pathogenic invasion by secretion of a variety of small antifungal proteins such as thionins. The transgenic potato cultivars generated were tested for fungal infection by using spore suspension on leaf and micro-tuber. The results showed that the new cultivars were highly resistant to the symptoms comparing to control. The other bioassay studied the effect of the expressed thionin proteins in the transgenic plant against the radial growth of both A. alternata and $R$. Solani and the diameter decrease.
\end{abstract}

Keywords: Alternaria alternata, chitosan, Rhizoctonia solani, Solanum tuberosum, Thionin gene, Transformation

\section{Introduction}

Solanum tuberosum belongs to the family Solanaceae, is a popular vegetable in the world and it is economically and socially important. It considered being the fourth most important food crop (after wheat, maize and rice). It is cultivated in temperate and subtropical regions across the world [1].

In Egypt, potato has an important value among all vegetable crops, where about $20 \%$ of total area devoted for vegetable production is cultivated with potato. Potato is the second most important vegetable crop after tomato. Potato is economically important to Egypt and any disturbance in its production affects severely its local and more importantly export impact. Because potato is one of the main crops among Egypt's agricultural exports, it is important to understand the relevant patterns and determinants of international trade in order to promote Egyptian agricultural exports. There are two main problems encounter production and exportation of potato in Egypt: infection with pathogenic diseases and using of chemical fungicides and pesticides. Firstly, during their seasonal plantations potato plants are subjected to numerous pathogens and insect pests which cause considerable loss in Egyptian quantitative and qualitative potato yield. Thus, a key barrier to the improvement of potato in Egypt is the reduction in yield and tuber quality caused mainly by potato pests and pathogens [2, 3 and 4]. Secondly, the use of pesticides and fungicides is costly as well as environmentally undesirable. Therefore, there is a great demand to develop novel strategies providing durable resistance, over a broad geographic area. Such strategies will be particularly important in cases where the source of resistance is not available. The most significant advancement in the area of varietal development for disease resistance is the use of the techniques of genetic engineering to develop transgenic plant resistant to many diseases [5,6,7,8 and 9].

Alternaria alternata and Rhizoctonia solani are common pathogenic fungi causing many diseases to potato plant. [10] Reported that Alternaria alternata is a fungus which causes leaf spot in potato plant. It occurs annually to some degree in most production areas, the timing of its appearance and the rate of disease progress help determine the impact on the potato crop. The fungus is considered to be a weak pathogen. This fungus can loss up to $20 \%$ of yield production and if uncontrolled; the disease can be very destructive.

Rhizoctonia solani is a soil borne fungus belongs to Basidiomycete. It is widely distributed over the world and is considered as an important causative fungal pathogen of various plants hosts causing different plant diseases (seed decay, seedlings damping off , leaves foliar blight, root rot), and other plant diseases [11].Black scurf is the most conspicuous sign of Rhizoctonia diseases. In this phase of the disease, the fungus forms dark brown to black, hard masses on the surface of the tuber of potato. These are called sclerotia and are resting bodies of the fungus [12].

Thionins are family of the PR proteins with low-molecular-weight (5 kDa) cysteine-rich proteins, they had anti-microbial activity and toxic to plant pathogens in vitro (has antifungal properties). There are many 
kinds of thionins, most of which mainly accumulate in seeds of higher plants. But some thionins exist in stems, roots, or leaves in tissue specific manner. $\mathrm{N}$ - and $\mathrm{C}$-terminal amino acid sequences of these thionins are highly conservative but their nucleotide sequences differentiate to each other [13, 14 and 15]. The mechanism of thionins inhibition to the pathogenic fungi was simply explained by [16] as follow: the antimicrobial properties of thionins are derived from their ability to induce pore formation on cell membranes of phytopathogens, resulting in release of potassium and calcium ions from the cell.

Gene delivery is a method for transformation using nanoparticle through non-viral-mediated delivery vehicles such as chitosan nanoparticle. [17]Mentioned that chitosan is a polymer that has been used extensively both in nucleic acid delivery and tissue engineering applications. [18]Enumerate the advantages of using nanoparticles rather than traditional carriers. Firstly, nanoparticles are applicable to both monocotyledons and dicotyledonous plants and any types of organs. Secondly, this type of gene carriers can effectively overcome transgenic silencing via controlling the copies of DNA combined to nanoparticles. Thirdly, nanoparticles can be easily functionalized so as to further enhance transformation efficiency. Finally, nanoparticles-mediated multigene transformation can be achieved without involving traditional building method of complex carrier.[19 and 20] described a cationic polymer that are stable and are an excellent choice for large-scale production and its commercial use as non-viral vectors known as chitosan. Chitosan (CS) is the only naturally existing cationic biodegradable alkaline polysaccharide and binds strongly to negatively charged DNA. Also [21] enumerated the properties of CS as it is a nontoxic, semicrystalline, biodegradable, biocompatible linear polysaccharide, chemical inertness, wound healing ability and low cost. It is a linear polysaccharide composed of randomly distributed $\beta$-(1-4)-linked D-glucosamine (deacetylated unit) and N-acetyl-D-glucosamine (acetylated unit). Recently, [22] approved that chitosan mixed with acrylamide, silicone and urea was used as fertilizer for crop plants.

In this study, we sought to introduce resistance potato plants to fungal pathogens by expressing antifungal Thionin proteins (Thio60 and Thio63). The two thionin genes were transformed into the potato tissues by using chitosan nanoparticle. We confirm that thionin gene can transfer into the transgenic potato cultivars, and then tested the resistance of transgenic plants with the fungal pathogen Alternaria alternata and Rhizoctonia solani.

\subsection{Plant material:-}

\section{Materials And Methods}

Arabidopsis thaliana plant is a genetic model of thionin genes. It was used to isolate the thionin genes. Two cultivars of Solanum tuberosum (potato) used as a transgenic model (lady and spunta). They were brought from Egyptian-Canadian Company (Egypt) and regenerated on MS media [23].

\subsection{Isolation of thionin genes from Arabidopsis thaliana:-}

The total genomic DNA of Arabidopsis thaliana was extracted using Edward's protocol described by [24]. For PCR reaction 50ng of template DNA was used for each $25 \mu \mathrm{l}$ reaction. Each reaction mixture contained $12.5 \mu 1$ of $2 \mathrm{X}$ master mix (Biolene), $0.25 \mu$ ltaqpolymerase (Biolene), $1 \mu \mathrm{l}$ of each forward and reverse primer ( $50 \mathrm{nmole} / \mathrm{base}$ ) and complete up to $25 \mu \mathrm{l}$ by sterile d.dH2O. The thionin primers were designed using snap gene ${ }^{\circledR}$ (2.3.3) software and there sequences were as follow: Thio60F: 5' GCTGAATTCATGGAGGACAAAAGA 3', Thio60R: 5' GCTAAGCTTTCATAGACTAAAATCAAT 3'; where Thio63F: 5' GCTGAATTCATGTTGGTGGCAG $3^{\prime}$ and Thio63R: 5' GCTAAGCTTAGTTTTTCTTGGTAC 3'. PCR reaction for each gene was performed for 40 cycles as follow: $1 \mathrm{~min}$ at $95^{\circ} \mathrm{c}, 1 \mathrm{~min}$ at $64^{\circ} \mathrm{c}$ and $1 \mathrm{~min}$ at $72^{\circ} \mathrm{c}$. The two thionin genes to be determined were AT1G12660 (Thio60) and AT1G12663 (Thio-63) genes and they are found on the chromosome one of Arabidopsis thaliana. PCR products for the isolated two thionin genes were run on $0.8 \%(\mathrm{w} / \mathrm{v})$ agarose gel. The amplified PCR products were purified using GeneJETTM PCR Purification Kit (Thermo K0701).

\subsection{Bacterial strain and plasmid:-}

The cultures of E. coli (CD3-389) containing pEGAD kindly provided from Agricultural center for genetic engineering and biotechnology (ACGEB) were grown for $24 \mathrm{~h}$ at $37^{\circ} \mathrm{c}$ on LB agar plates with the appropriate antibiotic for plasmid $(50 \mu \mathrm{g} / \mathrm{ml}$ kanamycin). Then make LB broth media at $200 \mathrm{rpm}$ in order to isolate the vector (pEGAD) using alkaline lysis method following the protocol of [25].

\subsection{Digestion, Cloning and bacterial transformation:-}

Both the two thionin genes and the vector (pEGAD) were digested with the same restriction enzymes (EcoRI and HindIII) from New England, Biolabs ${ }^{\circledR}$ Inc, according to the manufacture protocol. The ligation process was performed between the pEGAD plasmid and both inserts (Thio-60 and Thio-63 genes) respectively at conditions $37^{\circ} \mathrm{c}$ for $2 \mathrm{hr}$ [26]. So the ligation product is ready for proceeding bacterial transformation.

pEGAD vector carrying both Thio-60 and Thio-63 genes respectively were transformed into chemically competent E. coli cells. [26] Mentioned the protocol of E. coli transformation as follow: $100 \mu \mathrm{l}$ of 
competent cells were allowed to thaw on ice. $5 \mu 1$ of each plasmid DNA was added and incubated on ice for 30 minutes. Samples were subjected to $42^{\circ} \mathrm{C}$ for 1 minute and they were immediately transferred onto ice and left for 3 minutes. After heat shock $900 \mu \mathrm{l} \mathrm{SOC}$ medium was added onto bacterial culture. The samples were incubated at $37^{\circ} \mathrm{C}$ for $50-60$ minutes with shaking at $200 \mathrm{rpm} .100 \mu \mathrm{l}$ of each culture was spread onto wormed LB plate with $50 \mu \mathrm{g} / \mathrm{ml}$ kanamycin and were grown at $37^{\circ} \mathrm{C}$ overnight. After that, isolate the propagated plasmid with gene of interest in order to confirm the transformation into DH5 $\alpha$ by plasmid PCR.

\subsection{Plasmid PCR:-}

The vector (pEGAD) containing each of thionin genes were isolated from DH5 CD3-389 and a PCR reaction was established to confirm the cloning of the thionin genes inside the plasmid in the right direction $\left(5^{\prime}\right.$ 3) using the primers specific to the vector (pEGAD) as follow: Forward: 5' ACCTGCCAACCAAAGCGAGAAC 3' and reverse: 5' TCAGGGTTATTGTCTCATGAGCG 3'. PCR reaction for plasmid PCR was performed for 40 cycles as follow: 1 min at $95^{\circ} \mathrm{c}, 1 \min$ at $68^{\circ} \mathrm{c}$ and $1 \min$ at $72^{\circ} \mathrm{c}$. 2.6 Chitosan nanoparticle transformation:-

Chitosan nanoparticle was provided by Agricultural center for genetic engineering and biotechnology, Faculty of Agriculture, Ain-Shams University (ACGEB). The information of this nanoparticle like weight, $\mathrm{pH}$, degree of deacetylation and size were measured in order to estimate the percent of amino groups (carrying +ve charge) which unit with -ve charge of plasmid.

\subsubsection{Determination of degree of deacetylation of chitosan}

There are many methods for determination of degree of deacetylation of chitosan nanoparticle; one of them is titration method.[27] illustrated this method as follow: Dried chitosan $(0.2 \mathrm{~g})$ was dissolved in $20 \mathrm{~cm} 3$ $0.1 \mathrm{M}$ hydrochloric acid and $25 \mathrm{~cm}^{3}$ deionized water. After 30 minutes continuous stirring, next portion of deionized water $\left(25 \mathrm{~cm}^{3}\right)$ was added and stirring continued for 30 minutes. When chitosan was completely dissolved, solution was titrated with a $0.1 \mathrm{~mol} \cdot \mathrm{dm}^{-3}$ sodium hydroxide solution using automatic burette $(0.01$ $\mathrm{cm}^{3}$ accuracy). Degree of deacetylation (DA or DD) of chitosan was calculated using formula:

$D A[\%]=2.03 \cdot \frac{V_{2}-V_{1}}{m+0,0042 \cdot\left(V_{2}-V_{1}\right)}$

Where: $\mathrm{m}$ - weight of sample, V1, V2 - volumes of $0.1 \mathrm{~mol} \cdot \mathrm{dm}^{-3}$ sodium hydroxide solution corresponding to the deflection points, 2.03 - coefficient resulting from the molecular weight of chitin monomer unit, 0.0042 coefficient resulting from the difference between molecular weights of chitin and chitosan monomer units.

\subsubsection{Preparation of chitosan-DNA nanoparticles (CS/pDNA)}

[28] Described the method of CS/DNA formation as follow: Two types of CS, each of a different molecular weight, were dissolved separately in $25 \mathrm{mM}$ acetic acid, which was then adjusted to $\mathrm{pH} 5.5$ at a final concentration of $1 \%$ (stock solution). The stock solution was then diluted with distilled water to form different concentrations of CS solution $(0.01,0.02,0.04$ and $0.08 \%)$. The CS and the pEGAD were first incubated in water bath at $55^{\circ} \mathrm{C}$ for $15 \mathrm{~min}$, respectively. Then CS-DNA complexes were prepared by adding these CS different concentrations (working range of $0.01-0.08 \%$ ) to an equal volume of a pDNA solution $(50 \mathrm{mg} / \mathrm{ml}$ ) followed by immediately intense stirring on a vortex mixer for $1 \mathrm{~min}$.

(Note: for transformation with chitosan, the plasmid was dissolved in 50mM Sod. Sulfate)

\subsubsection{DNA retention and release}

The binding of pDNA with CS was determined by agarose gel electrophoresis method according to [29]. CS/pDNA different concentrations, ranging from 0.01 to $0.08 \%$, were loaded onto $1 \%$ agarose gel in Trisacetate/EDTA (TAE) buffer and electrophoresed at $60 \mathrm{~V}$ for $40 \mathrm{~min}$. Then, gels were visualized with a UV/white gel documentation system (VilberLourmat).

DNA release study was carried out according to [31]. Briefly, CS/pDNA NPs were centrifuged at $4^{\circ} \mathrm{C}$, $14,000 \mathrm{~g}$ for $30 \mathrm{~min}$, after which the pellet was resuspended in equal volume of phosphate-buffered saline (PBS, $\mathrm{pH}$ 7.4) and incubated at $37^{\circ} \mathrm{C}$ with $100 \mathrm{rpm}$ agitation for 3 days, then examined on Agrose gel electrophoresis.

\subsubsection{Transmission electron microscopy}

According to [32] the method for TEM imaging as follow: carbon coated 400 mesh copper grids were put over one drop of the complex (CS/pDNA) and left to stand for $1.5 \mathrm{~min}$. The grid was stained with one drop of filtered solution containing $2 \%$ uranyl acetate for $1.5 \mathrm{~min}$, and any excess uranyl acetate was removed with filter paper. The grids were allowed to dry for a further $10 \mathrm{~min}$ and then examined with a JEOL (JEM.1010) electron microscope in the Regional Center for Mycology and Biotechnology, Al-Azhar University.

\subsubsection{Transformation of Chitosan/pDNA into plant tissue:-}


Transformation of Chitosan/pDNA into plant tissue was carried out according to [33] as follow: nodal explants of $0.5-2.0 \mathrm{~cm}$ long were cut from the three-week old Solanum tuberosum cultivars plantlets. The explants were immersed in $300 \mu \mathrm{l}$ of CS/pDNA for 30 minutes. After that transfer these segments into $3 / 4 \mathrm{MS}$ medium containing hormones $(2 \mathrm{mg} / \mathrm{l} \mathrm{BA}$ and $1 \mathrm{mg} / \mathrm{l} \mathrm{kin})$ and $50 \mu \mathrm{g} / \mathrm{l} \mathrm{kanamycin}$ then incubated at $25 \pm 1^{\circ} \mathrm{C}$ for 4 weeks to regenerate plants. The produced transgenic potato cultivars were transferred into MS media containing rooting growth hormones $(1 \mathrm{ml} / 1 \mathrm{NAA}, 1 \mathrm{ml} / \mathrm{l} \mathrm{IBA}$ and $1 \mathrm{ml} / \mathrm{lkin})$ and incubated at $25^{\circ} \mathrm{c}$ under light conditions (16h light and $8 \mathrm{~h}$ dark for 4 weeks.

\subsection{Molecular analysis of transgenic plants:- \\ 2.7.1 PCR analysis}

A polymerase chain reaction (PCR) was employed to screen transformants for both thionin genes integration. Genomic DNAs from kanamycin-resistant and control potato plants 4-5 weeks old were extracted using a modified cetyl trimethyl ammonium bromide (CTAB) method [34]. PCR was performed using genomic DNA as a target and primers as follow: forward 60, 5'ATGGAGGACAAAAGAGTG3'; reverse 60, 5'TCATAGACTAAAATCAATAGC3'; forward 63, 5'ATGTTGGTGGCAGTAATGAT3'; and reverse 63, 5'CTAGTTTTTCTTGGTACACTT3'. These primers were designed by the software Oligo 7. PCR amplification reactions consisted of an initial denaturation at $95{ }^{\circ} \mathrm{C}$ for 3 min followed by 40 cycles of denaturation at $95{ }^{\circ} \mathrm{C}$ for $1 \mathrm{~min}$, annealing at $54^{\circ} \mathrm{C}$ for $1 \mathrm{~min}$, extension at $72{ }^{\circ} \mathrm{C}$ for $1 \mathrm{~min}$ and a post- extension at $72{ }^{\circ} \mathrm{C}$ for $10 \mathrm{~min}$. Taq DNA polymerase was used in all PCR reactions. The resulting PCR products were separated by electrophoresis agarose gel $1.2 \%(\mathrm{w} / \mathrm{v})$.

\subsubsection{Real time-PCR for the transgenic plant:-}

This reaction was performed in three steps: RNA extraction, cDNA synthesis and real time-PCR reaction. RNA was isolated from the transgenic line of both potato cultivars after four weeks cultivation in MS jars by using protocol of [35]. cDNA was generated from total RNA using usingSuperScript ${ }^{\circledR}$ III One-Step RT-PCR System with Platinum ${ }^{\circledR}$ Taq DNA Polymerase (Thermo scientific). Real-Time PCR reactions were carried out to quantify selected gene transcripts using PikoReal Real-Time (Thermo scientific) and SYBER-green as fluorescent dye, according to the manufacturer's instructions. The amplified PCR products were fractionated through 1\% agarose gel. These transcripts were compared to actin control gene (Act7) expressed in Arabidopsis thaliana plant. A melting curve was recorded at the end of every run to exclude primers generating non-specific PCR products.

\subsection{Fungal-resistance assay of transgenic plants:-}

Antifungal activity of the thionin genes in the transgenic plants thus obtained was tested against Alternaria alternata and Rhizoctonia solani.

\subsubsection{Spore suspension infecting different organs in potato}

In this experiment, spore suspension was prepared by immersing fungal discs in $5 \mathrm{ml}$ of sterile distilled water to release the spores. The spores were collected with a sterile Pasteur pipette, and their concentration was adjusted to $2 \times 10^{5}$ spores $/ \mathrm{ml}$ using sterile water. This assay was applied for detached leaves and micro-tubers. Detached leaves from mature transgenic and non-transformed potato plants, grown in vitro for 4-5 weeks, were placed in a Petri dish with wet filter paper, wounded in the middle on both sides of the midrib, and inoculated with the spore suspension $(20 \mu \mathrm{l}$ each). Micro-tubers from mature transgenic and non-transformed potato plants, grown in vitro for about 8 weeks, were placed in a Petri dish with wet filter paper and inoculated with the spore suspension $(20 \mu \mathrm{leach})$.After inoculation, these different organs were incubated at room temperature under $16 \mathrm{~h}$ light/8 h dark conditions and high humidity for a week. Pictures were taken 5 days after inoculation [36].

\subsection{Protein extraction Bioassay}

Antifungal activity of the product thionin proteins resulted in the transgenic potato was tested against the different potato pathogenic fungi spores. The protein extraction was applied following the method of [37]. Then the following bioassay was applied:-

\subsubsection{Inhibitory effect of protein extracts on radial growth}

The method was carried out according to [38] who determine the inhibitory effects of crude protein extracts, as they incorporated the extract into the PDA and poured into Petri dishes. Agar discs $(0.5 \mathrm{~cm}$ in diameter) were placed in the center of Petri dishes containing PDA with the crude protein extract. Petri dishes were sealed with parafilm. The plates without the protein extract were used as control. The plates were incubated for 4 days and mycelium growth was measured. 


\section{Results And Discussion}

In this study, chitosan nanoparticle transformation was employed to transform potato with two different thionin genes (AT1G12660 and AT1G12663). Two commercial potato cultivars, lady and spunta, were used in this study. Potato nodal cutting technique of tissue culture was used for transformation with chitosan nanoparticle. The transgenic plants exhibited enhanced resistance to Alternaria alternata and Rhizoctonia solani infection by the following:-

\subsection{Restriction digestion of thionin genes and vector:-}

Both two thionin genes (AT1G12660 and AT1G12663) and the vector pEGAD were digested with mixed (EcoRI and HindIII). The results were analyzed on agarose gel electrophoresis which illustrated in fig. (1). This work agreed with [14] who used thionin gene due to their antimicrobial effect for transformation into Magnaporthe oryzae. The usage of restriction digestion for gene insertion agreed with [39] who applied two restriction enzymes (HindIII and PstI) to open pSSA-F plasmid and insert their target genes (SOD and APX) respectively.
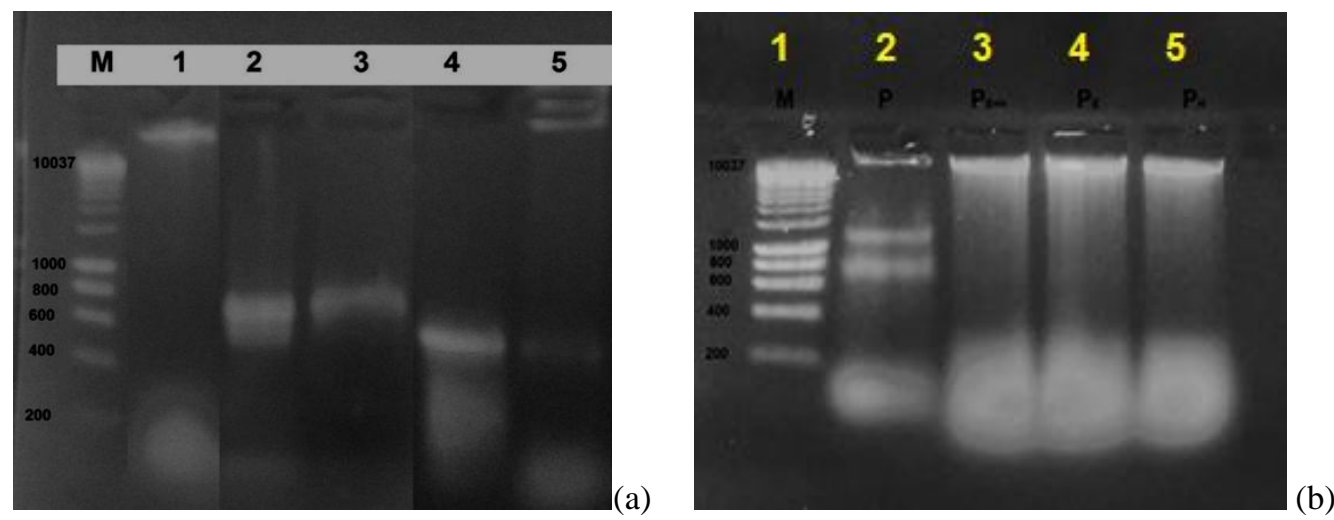

Figure (1) Agarose gel electrophoresis of the restriction digestion. (a) Restriction digestion of two thionin genes; M: Ladder 1kb, 1: genomic DNA of Arabidopsis thaliana, 2: AT1G12660 gene, 3: digested AT1G12660 gene, 4: AT1G12663 gene and 5: digested AT1G12663 gene. (b)Restriction digestion of plasmid, lane1 M: molecular weight ladder; lane 2: undigested pEGAD as a control; lane 3: EcoRI/HindIII linearized pEGAD; lane 4: EcoRI linearized pEGAD; lane 5: HindIII linearized pEGAD.

\subsection{Transformation by chitosan nanoparticle into plant tissue:-}

In this study CS/pDNA was successfully prepared with defined conditions and used as an effective gene delivery system. Chitosan nanoparticle was used for gene transformation into plant tissue. This agreed with [33] who used chitosan nanoparticle as a carrier of pBDG containing GFP gene through transformation into Paulownia sp and Echinacea purpurea plants.

\subsubsection{Determination of degree of deacetylation (DD):}

The simple titration method was used according to [27] who estimate of the DD assesses the amine or acetyl amine groups on the glycoside unit of chitosan nanoparticle. This group has a positive charge which binds with the negative charge of DNA and this determine the affinity between the nanoparticle and pDNA.The difference of the volumes of these two points (V1 and V2) corresponds to the acid consumed by the amine groups and allow to calculate DD. In order to know the characterization of chitosan nanoparticle, we measure several criteria as shown Table (1): the average value of DD was $56.626 \pm 10.016$, morphological descriptions: Amorphous, crispy, yellowish, molecular weights: $827 \mathrm{kDa}$, pH: 4.14, and particle size.

This Table (1) indicated that the high molecular weight chitosan was bound DNA more readily and the high DD samples were bound more efficient than lower DD. These results were the same manner with [32] who indicated that keeping the DNA concentration constant and changing of chitosan concentration. DNA binding is dependent on both molecular weight and the degree of deacetylation of the used chitosan, which proved that particle size and shape play an important role in transferring genes into the cells according to [40].

We must know these criteria because [31] mentioned that this characteristic is very important in gene transfer because cellular uptakes of the CS/pDNA complex as well as its subsequent release from the endolysosome pathway. 
Table (1) Description and characters of the provided chitosan samples

\begin{tabular}{|l|l|l|l|l|}
\hline Morphology & Mwt "KDa" & $\mathrm{pH}$ & Average DD & Particle size "nm" \\
\hline $\begin{array}{l}\text { Amorphous, crispy, } \\
\text { yellowish }\end{array}$ & $\begin{array}{l}827 \\
\text { (high Mwt) }\end{array}$ & 4.14 & $56.626 \pm 10.016$ & P60: $185.40 \pm 2.33$ \\
\cline { 5 - 5 } & & & P63: $183.27 \pm 3.12$ \\
\hline
\end{tabular}

\subsubsection{DNA retention and release}

Complex formation between chitosan and pDNA was confirmed using gel electrophoresis techniques. The optimal ratio of complex formation between chitosan and pDNA was 1:1 and this agree with [29] who use the same ratio of CS/pDNA 1:1, and it was confirmed by electrophoresis of complexes on an agarose gel fig. (2). The CS-DNA complex encapsulation capacity often depends on the molecular weight of CS. The results show that the extent of DNA retardation increases with an increasing ratio of CS/DNA (w/w) (Fig. 2; a, b). When pDNA is mixed with chitosan, the electrostatic interaction drives the formation of complexes. Run of pDNA on an agarose gel is retarded because of the charge neutralization and/or increase in molecular size of the complexes. The release of CS/pDNA complex was illustrated in fig. (3). The retention of CS/pDNA agreed with (30) who explained that the lack of electrophoretic mobility of the CS/pDNA confirms complete encapsulation, as no free plasmid bands were visible.
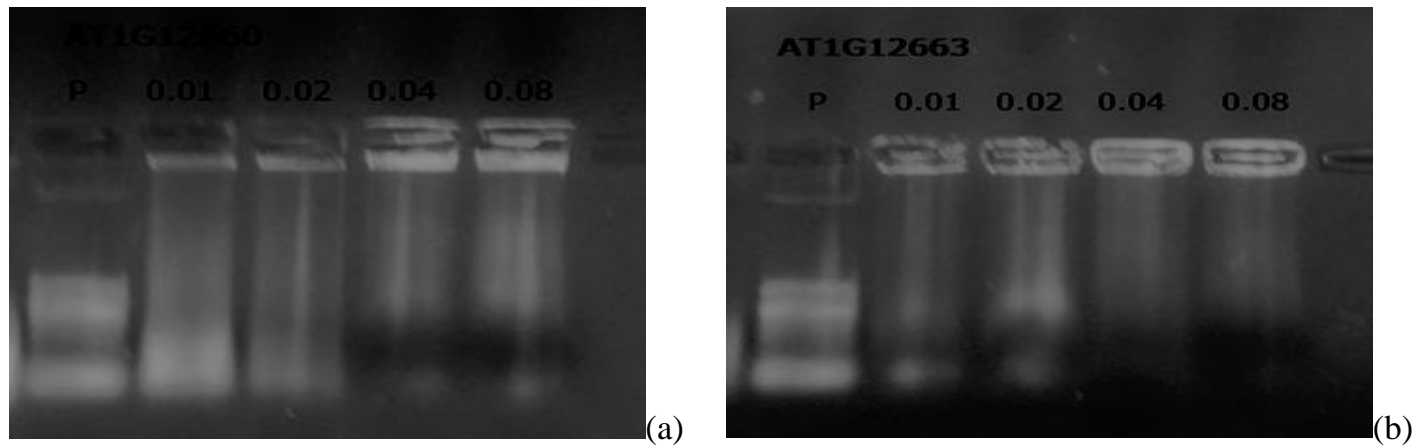

Figure (2) Agarose gel electrophoresis of CS-DNA. The binding of pDNA with CS was determined by $1 \%$ agarose gel electrophoresis in TBE buffer. Samples were analyzed by electrophoresis at $100 \mathrm{~V}$ for $20 \mathrm{~min}$. (A) CS-pDNA (AT1G12660 gene) complex. Lane 1: naked pEGAD-DNA; lane 2-5: CS/pDNA with different CS concentrations. (B) CS1-DNA (AT1G12663 gene) complex. Lane 1: naked pEGAD-DNA; lane 2-5: CS1/pDNA with different CS concentrations.
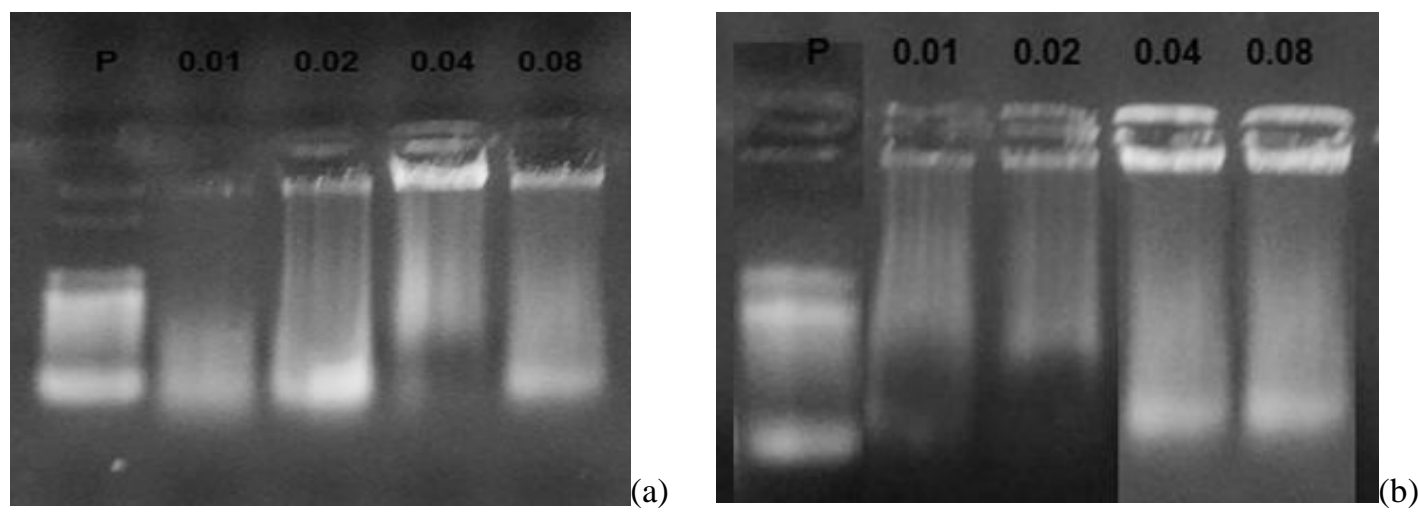

Figure (3)Agarose gel electrophoresis of Chitosan release from pDNA. (a) CS/P60 release and (b) CS/P63 release.

\subsubsection{Transmission electron microscope (TEM)}

Chitosan nanoparticle morphology was characterized using transmission electron microscopy (fig.4). This figure explained firstly the retention between CS NP and pDNA, secondly measurements the size of these chitosan particles shown in table (2) which explained that there is no significant difference between both genes which loaded into chitosan, it could be attributed to have nearly the same length. The images obtained by TEM were illustrated in fig. $(4 a, b)$ which showed that white dots is CS while black dots are pDNA.

The imaging of CS/pDNA complex under TEM agreed with [32] who photographed chitosan with pcDNA containing human embryonic kidney cells (HEK293); and [41] who photographed pUMVC3-hIL12 loaded chitosan nanoparticles in Colon Carcinoma Cells. Up till now few researches included application of 
chitosan in plant and the work in this field is too narrow, [33] who imaged the pBDG loaded to chitosan complex which transfected in both Echinacea purpurea and Paulownia sp plants respectively.

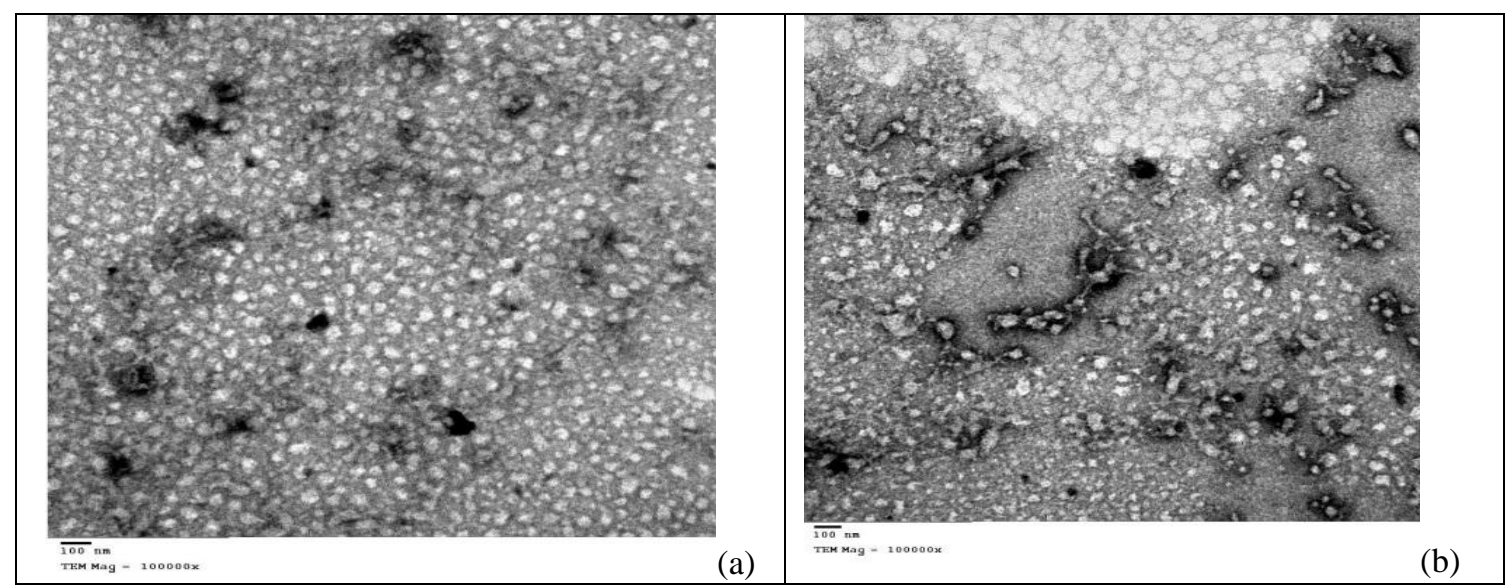

Figure (4) Transmission electron microscopy of chitosan nanoparticle binding with pEGAD carrying both thionin genes: (a) CS/P60, (b) CS/P63. Image scales: 100nm.

\subsubsection{CS/pDNA transfection into plant tissue}

In this experiment, CS was investigated as potential delivery systems for pDNA in vitro. The internodes of two potato cultivars were immersed in the different concentrations of CS/pDNA mix $(0.01,0.02$, 0.04 and $0.08 \% \mathrm{CS}$ ) for $30 \mathrm{~min}$ then transferred into MS media with $50 \mu \mathrm{g} / \mathrm{ml}$ kanamycin and growth hormones (2mg/l BA and $1 \mathrm{mg} / \mathrm{l} \mathrm{kin).} \mathrm{After} \mathrm{four} \mathrm{weeks} \mathrm{incubation} \mathrm{at} 25^{\circ} \mathrm{c}$ under light conditions, the shoots are fully grown and multiplied, then test for gene transfer. The transformed potato with Thio60 and Thio63 genes via CS were shown in fig. (5). Similar findings were obtained by [33] who use chitosan transformation into nodal plant segments for $30 \mathrm{~min}$, also agreed with [42] who used the same growth hormones in MS media for the transformed nodal potato segments.

In this study, we selected nodal explants for transformation because [43] proved that the nodal explants are much more resistant during manipulation and more amenable to in vitro conditions. While, [44] mentioned that the leaf explants were easily injured during the manipulation, which resulted in a low percentage of transformation.

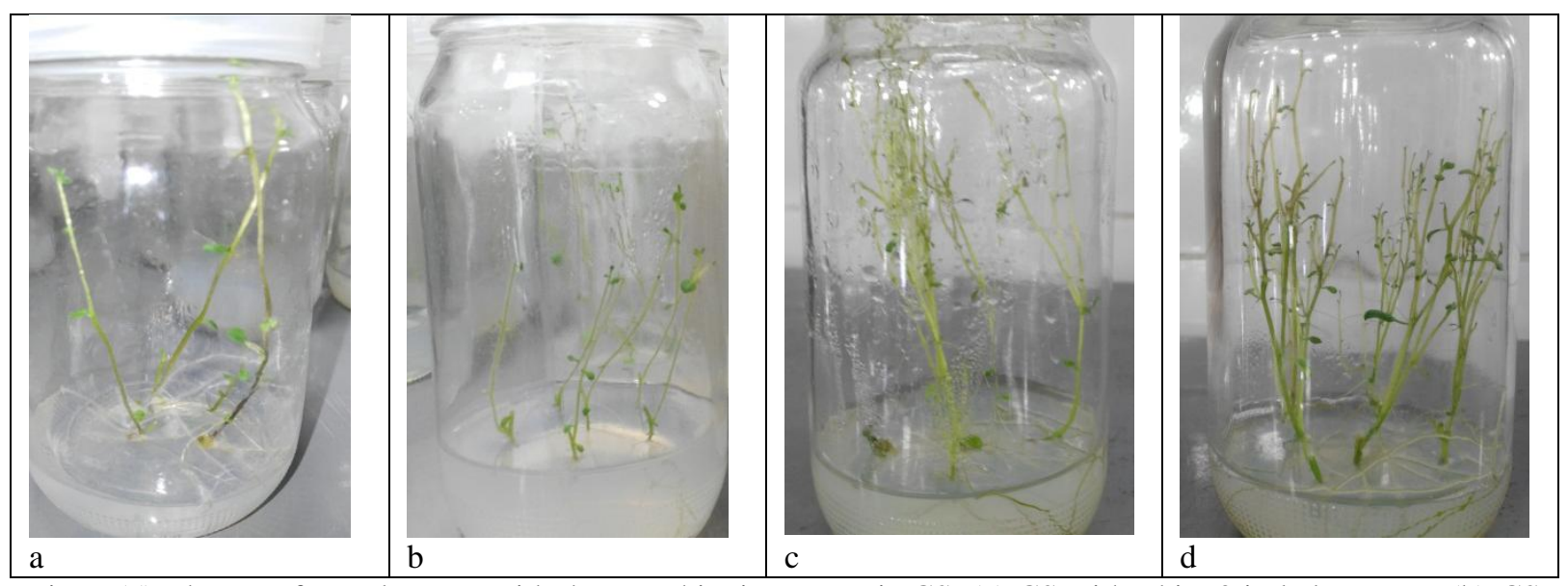

Figure(5) The transformed potato with the two thionin genes via CS. (a) CS with Thio60 in lady potato; (b) CS with Thio63 in lady potato; (c) CS with Thio60 in spunta potato; (d) CS with Thio63 in spunta potato.

\subsection{Molecular analysis of the transgenic plant}

\subsubsection{PCR analysis:-}

The kanamycin-resistant clones were subjected to PCR analysis to confirm the integration of the transgenes Thionin 60 and thioinin 63. Some clones showed amplified fragments of approximately $0.6 \mathrm{~kb}$ for thionin 60 in both lady and spunta cultivars (Fig. 6a,b) and $0.4 \mathrm{~kb}$ for thionin 63 in both lady and spunta cultivars (Fig. 6c,d).No amplified band was shown in PCR products from total DNA of non-transformed control plants. These findings are similar to [45] who used PCR to confirm OC-II, OC-I genes transformation 
respectively into transformed potato plant; and [45] who apply PCR to confirm the presence of the plasmid pSKI074 into transformed potato plant.
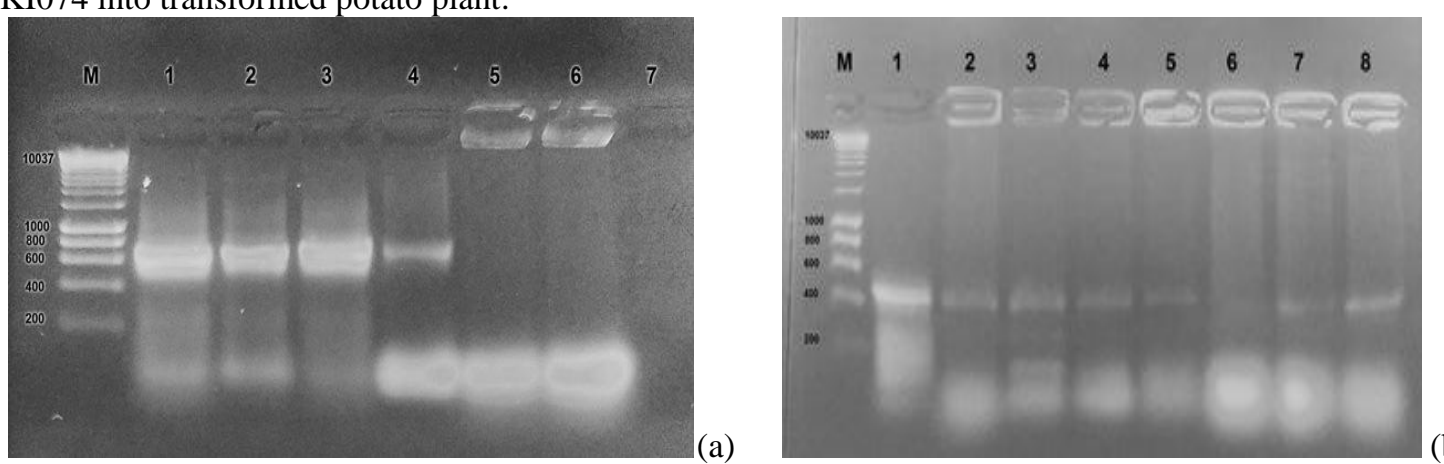

(b)
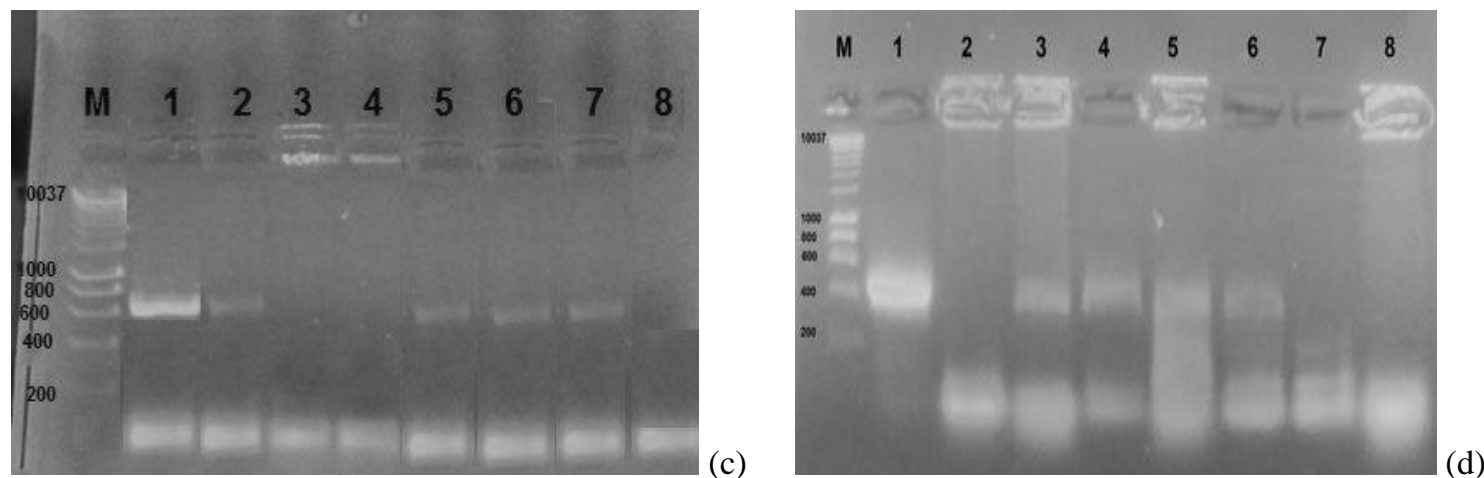

Figure(6) Polymerase chain reaction (PCR) analysis of potato transformed with thionin 60 and thionin 63 genes. a) Amplified fragments of thionin 60 gene in lady cultivar $(0.64 \mathrm{~kb})$, b) amplified fragment of thionin 60 gene in spunta cultivar $(0.64 \mathrm{~kb}), \mathrm{c})$ amplified fragments of thionin 63 gene in lady cultivar $(0.48 \mathrm{~kb})$, d) amplified fragment of thionin 63 gene in spunta cultivar $(0.48 \mathrm{~kb})$.

\subsubsection{RT-PCR:-}

The reverse transcription of RNAs into cDNAs and the amplification of the specific regions of both Thio60 and Thio63 genes were done to detect the transcript expression. The result of RT-PCR showed a single $414 \mathrm{bp}$ amplification product for Thio60 gene and a single $348 \mathrm{bp}$ amplification product for Thio63 gene. The expression of both thionin genes in transgenic potato is lower than level of transcript expression than actin control gene expressed in Arabidopsis plant. Fig. (7) Showed the expression level of both thionin transcripts in the two potato cultivars in comparing to control transcripts in Arabidopsis plant. The application of RT-PCR for gene expression within the transformed potato plant agreed with [47] who tested the transcripts of human proinsulin gene within three transformed potato cultivars (Desiree, Agria and Marfona).



Figure (7) qRT-PCR for Thionin transcripts in transgenic potato cultivars (lady and spunta) 


\subsection{Pathogenicity test:-}

The results of spore suspension of both A. alternata and $R$. solani on different parts of control and transgenic potato cultivars (detached leaf and micro-tuber) were recorded in Table (2). The effect of these different pathogenic fungi on the detached leaf and micro-tuber were illustrated in histogram in fig. (8) and their effect on morphology of detached leaf and micro-tubers were shown in fig.(9 and 10 respectively).

Fungal resistance of transgenic potato plants expressing thionin genes isolated from Brassicaceae species (Arabidopsis thaliana) was evaluated against the phytopathogenic fungi, Alternaria spp as mentioned in recommendtion by [13] who worked on Botrytis cinerea as phytopathogenic fungus to potato. Thionins inhibit the growth in vitro of about 20 different fungal plant pathogens including Botrytis cinerea, Fusarium spp., Phytophthora infestans and Rhizoctonia solani [48]. As to their mode of action, thionins are known to form cation-selective ion channels by binding to phosphatidylserine head groups in lipid bilayer membranes which cause permeabilization and oxidative burst followed by cell death in target cells [49,50 and 51]. The mechanism also explained simply by [16] as follow: the antibacterial and antifungal properties of thionins are derived from their ability to induce pore formation on cell membranes of phytopathogens, resulting in release of potassium and calcium ions from the cell.

Table (2) The effect of spore suspension of A. alternata and R. solanion different potato organs

\begin{tabular}{|l|l|l|l|l|l|}
\hline \multirow{3}{*}{ Fungi } & Transgene & \multicolumn{4}{l|}{ Parameter } \\
\cline { 3 - 6 } & & Detached leaf & Micro-tuber \\
\cline { 3 - 6 } & & Lady & Spunta & Lady & Spunta \\
\hline \multirow{4}{*}{ A. alternata } & Control & 23.868 & 23.457 & 15.878 & 17.461 \\
\cline { 2 - 6 } & CS-60 & 7.407 & 8.000 & 5.791 & 5.232 \\
\cline { 2 - 6 } & CS-63 & 8.766 & 8.389 & 6.830 & 6.740 \\
\cline { 2 - 6 } & Average Inh.\% & 66.119 & 65.066 & 60.256 & 65.718 \\
\hline \multirow{3}{*}{ R. solani } & Control & 36.336 & 37.924 & 22.345 & 23.908 \\
\cline { 2 - 6 } & CS-60 & 15.145 & 14.069 & 8.964 & 7.345 \\
\cline { 2 - 6 } & CS-63 & 16.782 & 16.808 & 7.234 & 8.829 \\
\cline { 2 - 6 } & Average Inh.\% & 56.067 & 59.291 & 63.755 & 66.174 \\
\hline
\end{tabular}

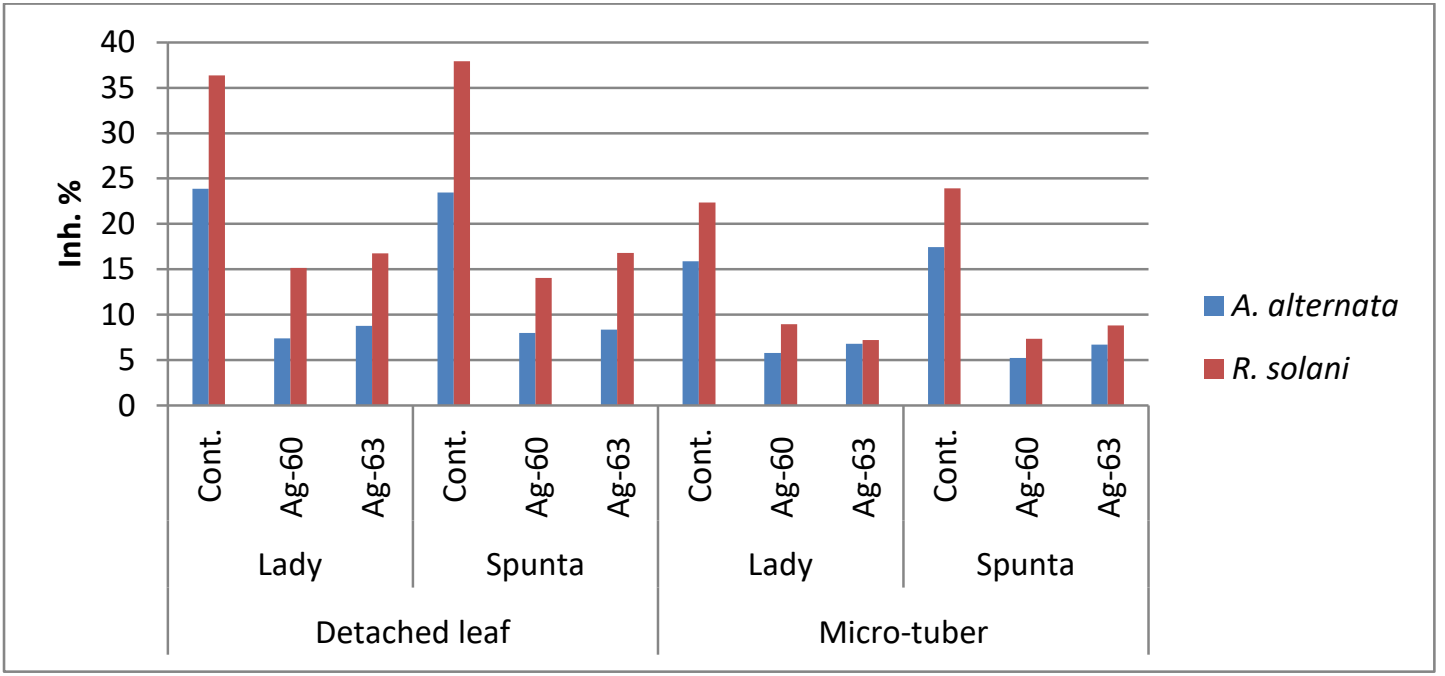

Figure (8)Histogram showing the inhibition percentage of A. alternata and R. solani affecting detached leaf and micro-tuber in both lady and spunta cultivars (in case of control and transgene: Ag-60 and Ag-63).






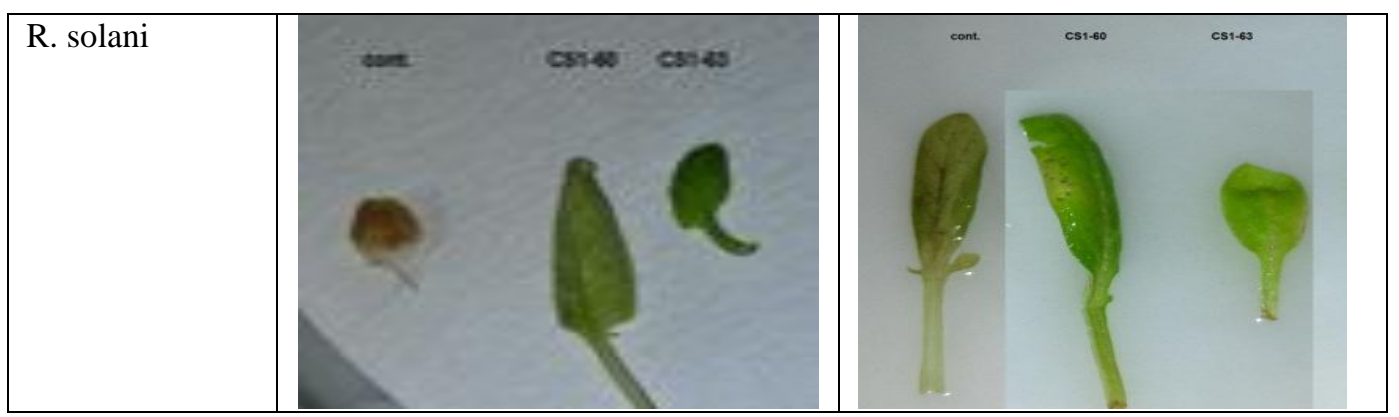

Figure (9) The effect of spore suspension of A. alternata and R. solanion detached leaf of potato cultivars. (The arrangement is as follow: control, transgenic with Agor.60 and transgenic with Agro.63).

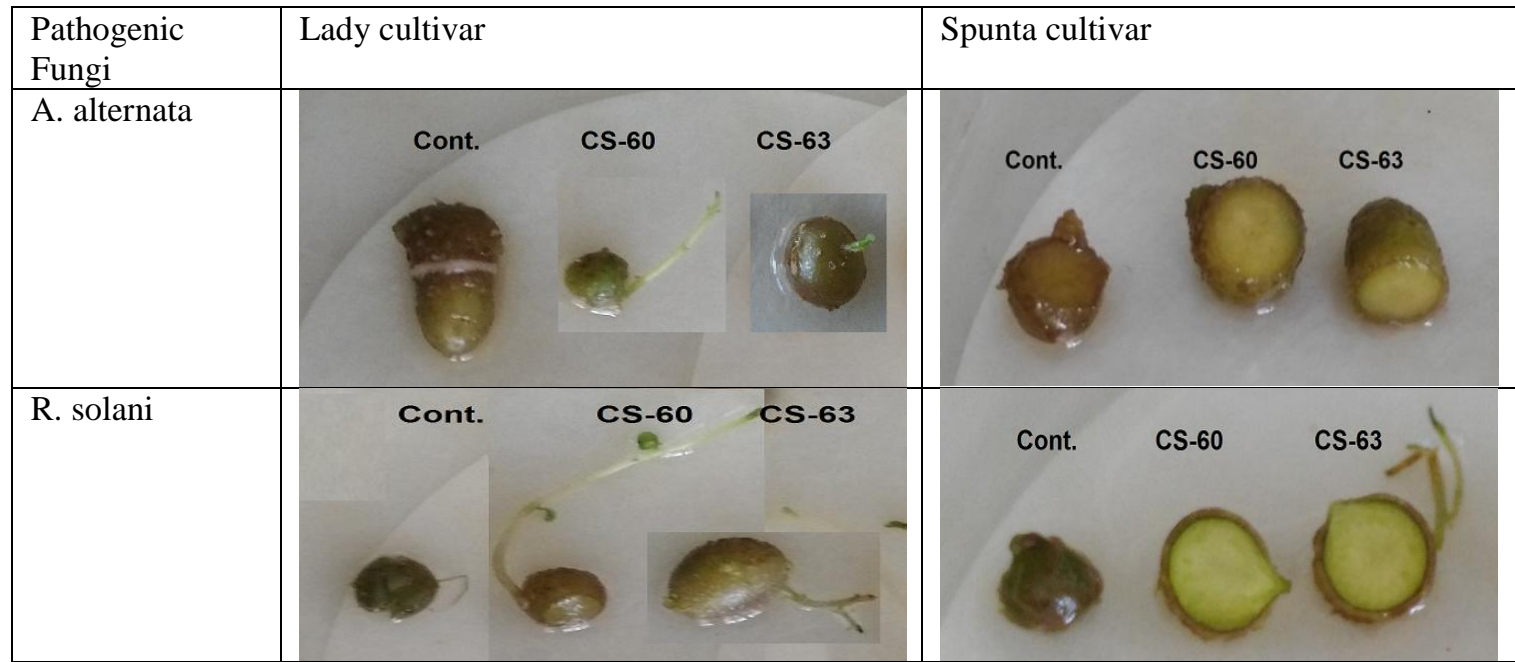

Figure (10) The effect of spore suspension of A. alternata and $R$. solani on micro-tuber of potato cultivars. (The arrangement is as follow: control, transgenic with CS-60 and transgenic with CS-63).

\subsection{Inhibitory effect of protein extracts on radial growth of fungi}

It is evident that protein extract of five replicates of transgenic potato that contain thionin proteins showed antifungal activity against the different pathogenic fungi with reduction in mycelial growth. Fig. (11) illustrate the inhibitory effect of protein extract of the transgenic potato cultivars on radial growth of the PDA plates of different four pathogenic fungi after incubation for 7 days at $28^{\circ} \mathrm{c}$ in comparing to control fungi. From Table (3) and histogram in fig. (12) it was obvious that Thio63 protein cause more inhibition for the radial growth of both A. alternate and $R$. solani. These results agreed with [16] who worked on the secreted antifungal thionin protein isolated from Arabidopsis thaliana and suppressed the toxicity of fungal wall.

Table (3) Effect of protein extracts on radial growth of A. alternata and R. solani

R.G: Radial growth, Inh \%: Inhibition (\%)

\begin{tabular}{|c|c|c|c|c|}
\hline \multirow[t]{2}{*}{ Fungi } & \multicolumn{2}{|c|}{ Thio60 protein } & \multicolumn{2}{|c|}{ Thio63 protein } \\
\hline & R.G. "cm" & Inh. \% & R.G. "cm" & Inh. \% \\
\hline A. alternata & $1.790 \pm 0.240$ & 37.19 & $1.776 \pm 0.063$ & 37.66 \\
\hline R. solani & $5.200 \pm 0.153$ & 42.22 & $4.400 \pm 0.208$ & 51.11 \\
\hline
\end{tabular}

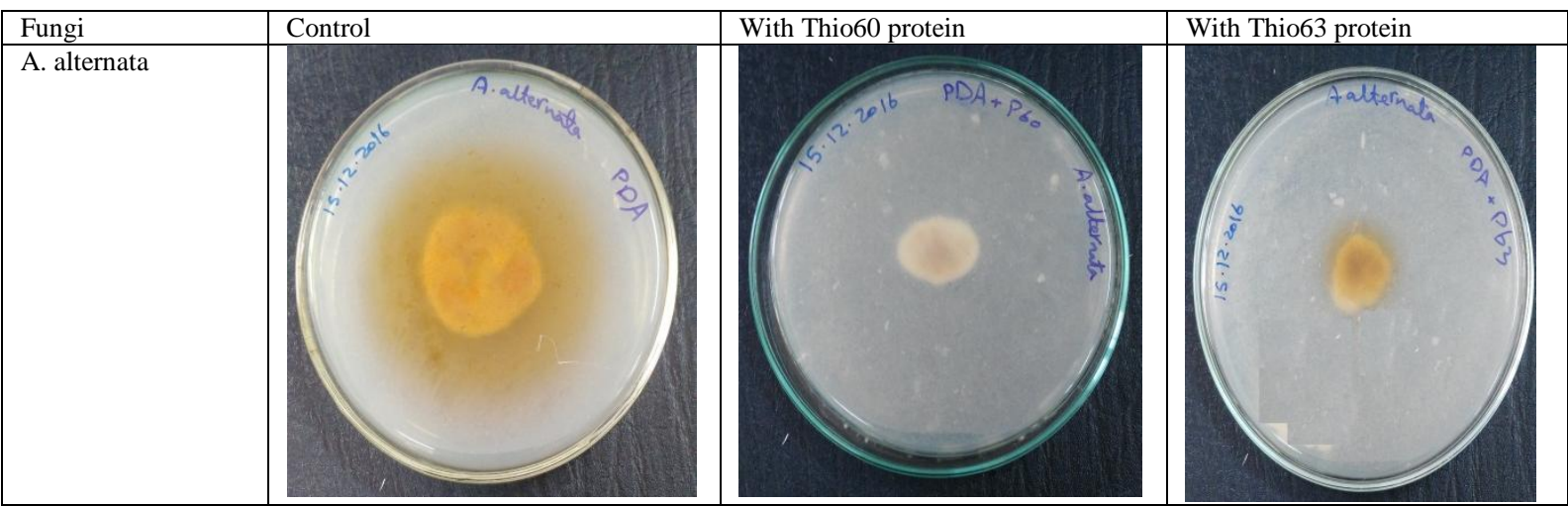




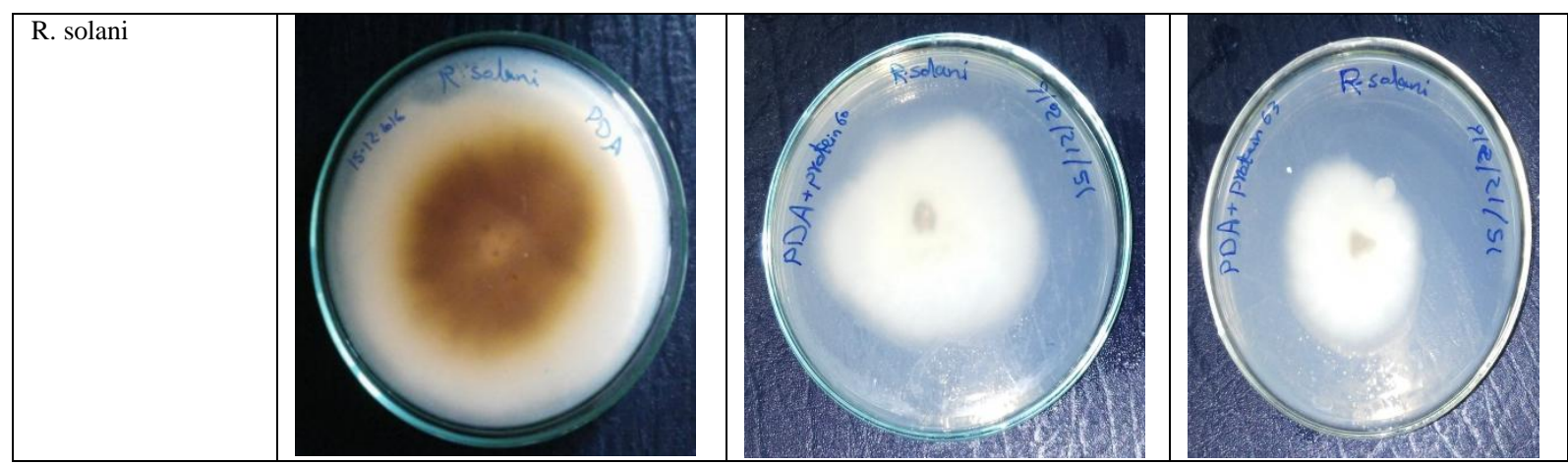

Figure (11) The inhibitory effect of protein extract on the radial growth of A. alternata and R. solani

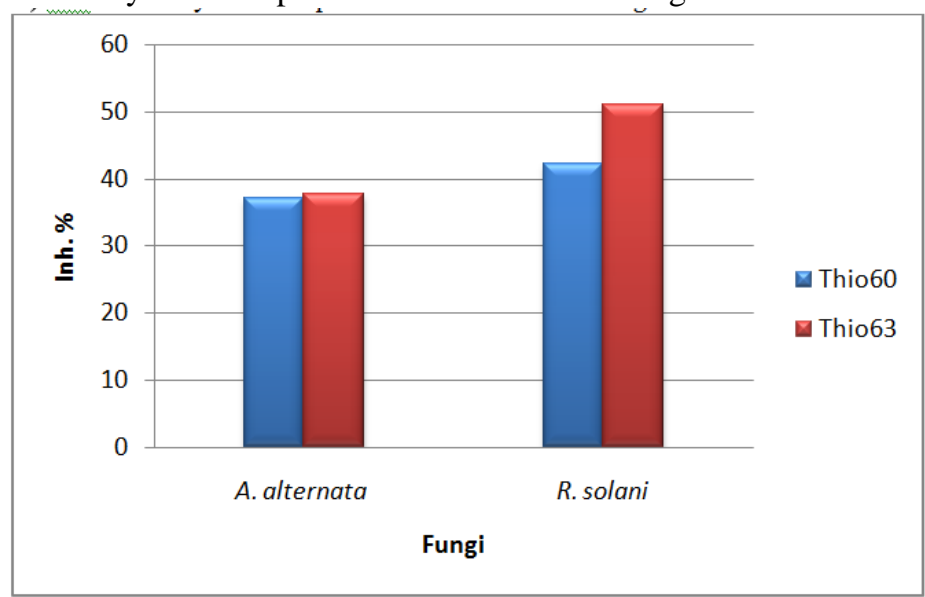

Figure (12) Histogram showing the inhibition percentage of thionin proteins (Thio60 and Thio63) on radial

\section{Acknowledgements}

growth

The corresponding author gratefully acknowledge Mr. Mohammed Fathy (Tissue culture laboratory, Agricultural center for genetic engineering and biotechnology "ACGEB", Faculty of Agriculture, Ain Shams University) for his effort in this work in the part of tissue culture of potato plant.

\section{References}

[1]. J.E. Edmonds, M.S. Vorontsova, and S. Knapp, Solanaceae, In: Flora of Tropical East Africa, ed. H. Beentje, Royal Botanic Gardens, Kew, 2012

[2]. S.S.Kabeil, S.M.Lashin, M.H.El- Masry, M.A.El-Saadani, M.M. Abd-Elgawad, and A.M. Aboul-Einean,: Potato Brown Rot Disease in Egypt: Current Status and Prospects, American-Eurasian J. Agric. and Environ. Sci., 4 (1),2008, 44-54.

[3]. S.I.A Elawady and A.Y. Abdulkheir, An Economic Study of the Growth Determinants for the Egyptian Potatoes Exports to the Global Market, International Journal of Economics and Finance, 7(7),2015, 89-97.

[4]. H.A.M.Mahgoub, G.S.A. Eisa and M.A.H. Youssef, Molecular, biochemical and anatomical analysis of some potato (Solanum tuberosum L.) cultivars growing in Egypt, Journal of Genetic Engineering and Biotechnology, Elseveir. 13, 2015,39-49.

[5]. M.A.Draper, G.A. Secor and H.A.Lamey, Managements of potato diseases in the home garden. NDSU; 1994,1-8.

[6]. L. Tamm,B.Smit,M.Hospers, B.Janssens, J.Buurma, J.P.Mølgaard, P.E.Lærke, H.H.Hansen, L.Bodker, C.Bertrand, J.Lambion, M.R.Finckh, C.Schüler, E.Lammerts van Bueren, T.Ruissen, S.Solberg, B.Speiser, M.Wolfe, S.Phillips, S.J.Wilcockson, C.Leifert, Assessment of the socio-economic impact of late blight and state-of-theart management in European organic potato production systems, (published by FiBL; Frick, Switzerland),Chapter two,2004,15-119.

[7]. H.Zhang, G. Li,W. Li and F.Song, Transgenic strategies for improving rice disease resistance, African Journal of Biotechnology 8 (9), 2009, 1750-1757.

[8]. [8] A.S. Walker, A. Micoud, F. Rémuson, J. Grosman, M. Gredt and P. Leroux, French vineyards provide information that opens ways for effective resistance management of Botrytis cinerea (greymould), PestManagSci 69, 2013,667-678.

[9]. H. Van der Heyden, P. Dutilleul, L. Brodeur and O. Carisse, Spatial distribution of single nucleotide polymorphisms related to fungicide resistance and inference for sampling, 2014.

[10]. W. Kirk, and P. Wharton, Brown Leaf Spot. Michigan potato disease. Extension Bulletin E3182, 2012

[11]. T.M. Muhsin and M.S. Selman, In vitro, optimization ofgrowth and bioactivity of antibacterial metabolite produced by Rhizoctoniasolani Kuhn, Journal of Basrah Researches ((Sciences)) 39(1),2013, 101-111.

[12]. P. Wharton, W. Kirk, D. Berry, and S. Snapp, Michigan potato diseases, Rhizoctonia stem canker and blackscurf of potato, Michigan extension bulletin.2007.

[13]. K. Hoshikawa, G. Ishihara, H. Takahashi and I. Nakamura, Enhanced resistance to gray mold (Botrytis cinerea) in transgenic potato plants expressing thionin genes isolated from Brassicaceae species, Plant Biotechnology 29,2012, 87-93.

[14]. Z. Sadati, M.A. TajikGhanbari,V. Babaeizad, and H. Rahimian, Expression of thionin and PDF1.2 coding genes as antimicrobial peptides in interaction of rice against rice blast agent, Magnaporthe oryzea, Iran. J. Plant Path., 50 (4), 2014, 147-149. 
[15]. K.Y.Kurtoglu, E. Filiz, I.I.Ozyigit and R. Vatansever,Genome-Wide Analysis of Thionin Genes in Higher Plants, Plant and animal genome conference XXIII. San Diego, CA.2015.https://pag.confex.com/pag/xxiii/webprogram/Paper14677.html

[16]. T. Asano, A. Miwa, K. Maeda, M. Kimura, and T. Nishiuchi, The Secreted Antifungal Protein Thionin 2.4 in Arabidopsis thaliana Suppresses the Toxicity of a Fungal Fruit Body Lectin from Fusarium graminearum, PLoSPathog 9(8): 2013, e1003581.

[17]. R. Raftery, F.J. O'Brien and S.A. Cryan, Chitosan for Gene Delivery and Orthopedic Tissue Engineering Applications, Molecules, $18,2013,5611-5647$.

[18]. F. Yu-qin, L. Lu-hua, W. Pi-wu, Q. Jing, F. Yong-ping, W. Hui, S. Jing-ran and L. Chang-li, Delivering DNA into Plant Cell by Gene Carriers of ZnS Nanoparticles, Chem. Res. Chinese Universities, 28(4),2012, 672-676.

[19]. K. Singh and A. Mishra, Water Soluble Chitosan Nanoparticle for the Effective Delivery of Lipophilic Drugs, A Review,Int J App Pharm, 5(3), 2013, 1-6

[20]. G. Li, J. Wang, X.Feng, Z. Liu, C. Jiang and J. Yang, Preparation and Testing of Quaternized Chitosan Nanoparticles as Gene Delivery Vehicles, Appl.Biochem.Biotechnol., 175, 2015, 3244-3257.

[21]. J. Vinsova and E. Vavrikova, Recent advances in drugs and prodrugs design of chitosan,Curr. Pharm. 17(32), 2011, 3596-607.

[22]. S.I. Siafu, Silicone Doped Chitosan-Acrylamide Coencapsulated Urea Fertilizer: An Approach to Controlled Release Fertilizers. Journal of Nanotechnology, Hindawi Publishing Corporation, Article ID 8490730, 7 pages, 2017 https://doi.org/10.1155/2017/8490730.

[23]. T. Murashige and K. Skoog, A revised medium for rapid growth and bioassays with tobacco tissue cultures, Physiol. Plant, 15,1962, 473-497.

[24]. Y. Lu,S. Chanroj, L. Zulkifli, M.A. Johnson, N. Uozumi, A. Cheung and H. Sze, Pollen tubes lacking a pair of K+ transporters fail to target ovules in Arabidopsis. Plant Cell 23(1),2011, 81-93.

[25]. T. Maniatis, E.F. Fritsch, J. Sambrook, Molecular cloning: A laboratory manual. (2nd ed.). Cold spring harbor laboratory, New York, U.S.A.1989.

[26]. M. Kavas, Development of salt resistant transgenic plants by using TANHX1 and TASTR genes. Thedegree of doctor of philosophy in biology, the graduate school of natural and applied sciences of middle east technical university, 2011.

[27]. R. Czechowska-Biskup, D. Jarosińska, B.Rokita, P. Ulański and J.M. Rosiak, Determination of degree of deacetylation of chitosan - comparison of methods, Progress on Chemistry and Application of Chitin and Its derivatives, Volume XVII, p,2012, 5-20.

[28]. S. Mansouri, Y. Cuie, F. Winnik, Q. Shi, P. Lavigne, M. Benderdour and E. Beaumont, Characterization of folate-chitosan-DNA nanoparticles for gene therapy, Biomaterials, 27,2006, 2060-2065.

[29]. X.W. Li, D.K. Lee,A.S. Chanand H.O. Alpar, Sustained expression in mammalian cells with DNA complexed with chitosan nanoparticles, BiochimBiophysActa, 1630,2003, 7-18.

[30]. H. Bordelon, A.S. Biris, C.M. Sabliov, W.T. Monroe, Characterization of Plasmid DNA Location within Chitosan/PLGA/pDNA Nanoparticle Complexes Designed for Gene Delivery. Journal of Nanomaterials, Hindawi Publishing Corporation. Article ID 952060, 9 pages. doi:10.1155/2011/952060, 2011

[31]. M. Huang, C.W. Fong, E. Khor and L.Y. Lim, Transfection efficiency of chitosan vectors: effect of polymer molecular weight and degree of deacetylation, J Control Release, 106,2005, 391-406.

[32]. T. Kiang, J. Wen, H.W. Lim and K.W. Leong, The effect of the degree of chitosan deacetylation on the efficiency of gene transfection, Biomaterials Elsevier Ltd., 25, 2004, 5293-5301.

[33]. H.M. Nour El-Hoda: Evaluation of Nano-Particles Transfer of Bio-Control Related Gene (S) Via Gene Expression, Unpublished M. Sc. Thesis, Department of Genetics, Faculty of Agriculture, Ain Shams University, 2017.

[34]. S. Yadav, P. Sharma, A. Srivastava, P. Desai and N. Shrivastava, Strain specific Agrobacterium-mediated genetic transformation of Bacopamonnieri, Journal of Genetic Engineering and Biotechnology 12,2014, 89-94.

[35]. I. Jordon-Thaden, A.S. Chanderbali, M.A. Gitzendanner and D.E. Soltis, Modified CTAB and Trizol protocols improve RNA extraction from chemically complex embryophyta, Applications in Plant Sciences 3 (5), 2015, 1400105 (1-22).

[36]. R.S. Khan,R. Sjahril, I. Nakamura, M. Mii, Production of transgenic potato exhibiting enhanced resistance to fungal infections and herbicide applications, Plant Biotechnol Rep 2, 2008, 13-20.

[37]. M.M. Bradford, A Rapid and Sensitive Method for the Quantitation of Microgram Quantities of Protein Utilizing the Principle of Protein-Dye Binding, Anal.,Biochem. 72,1976, 248-254.

[38]. A.H. Ashraf, H. B. Ali, E. Mohamed, M.E. Abdallah and A.E. Mohamed, Inhibitory Influence of Plant Extracts on Soil Borne Fungi Infecting Muskmelon (Cucumismelo L.), International Journal of Pharmacology, 10,2014, 322-327.

[39]. R. Ahmad, Y.H. Kim, M.D. Kim, M.N.Phung, W.I. Chung, H.S. Lee, S.S. Kwak and S.Y. Kwon, Development of Selection Marker-free Transgenic Potato Plants with Enhanced Tolerance to Oxidative Stress, Journal of Plant Biology, 51(6),2008, 401-407.

[40]. M. Bivas-Benita, S. Romeijn, H.E. Junginger and G. Borchard, PLGA-PEI nanoparticles for gene delivery to pulmonary epithelium,Eur J Pharm Biopharm, 58,2004, 1-6.

[41]. S. Hallaj-Nezhadia,H. Valizadeha, S. Dastmalchia,B. Baradaranc, M.B. Jalalia, F. Dobakhtidand F. Lotfipoure, Preparation of Chitosan-Plasmid DNA Nanoparticles Encoding interleukin-12 and their Expression in CT-26 Colon Carcinoma Cells, J Pharm PharmaceutSci; 14(2),2011, $181-195$.

[42]. R.H. Sarker and B.M. Mustafa,Regeneration and Agrobacterium-mediated Genetic Transformation of Two Indigenous Potato Varieties of Bangladesh, Plant Tissue Cult., 12(1),2002, 69-77.

[43]. A. Beaujean, R.S.Sangwan, A. Lecardonnel and B.S. Sangwan-Norreel, Agrobacterium-mediated transformation of three economically important potato cultivars using sliced internodal explants: an efficient protocol of transformation, Journal of Experimental Botany, 49(326),1998, 1589-1595.

[44]. M. De Block, Genotype-independent leaf disc transformation of potato (Solanum tuberosum) using Agrobacterium tumefaciens, Theoretical and Applied Genetics 76, 1988, 767-74.

[45]. A. Cingel, B.Vinterhalter, D. Vinterhalter, D. Cali-Dragosavac, A. Smigocki and S. Ninkovi, Agrobacterium-mediated transformation of two Serbian potato cultivars (Solanum tuberosum L. cv. Dragaevka and cv. Jelica), African Journal of Biotechnology, 9(30),2010,4644-4650.

[46]. B. Chakravarty and G. Wang-Pruski, Rapid regeneration of stable transformants in cultures of potato by improving factors influencing Agrobacterium-mediated transformation, Advances in Bioscience and Biotechnology, 1, 2010, 409-416.

[47]. K. Kashani, M.J. Javaran, M. Mohebodini, A. Moieni, M. Sheikhi and D. Abadi,Regeneration and Agrobacterium-mediated transformation of three potato cultivars (Solanum tuberosum cv. Desiree, Agria and Marfona) by human proinsulin gene, AJCS, 6(7), 2012, 1212-1220

[48]. B.P.A.Cammue, M.F.C.De Bolle, F.R.G.Terras, P.Proost, J. Van Damme, S.B. Rees, J. Vanderleydenand W.F. Broekaert, Isolation and characterization of a novel class of plant antimicrobial peptides from Mirabilis jalapa L. seeds, Journal of Biological Chemistry, 267,1992, 2228-2233. 
[49]. P. Hughes, E. Dennis, M. Whitecross, D. Llewellyn and P. Gage, The cytotoxic plant protein, beta-purothionin, forms ion channels in lipid membranes, Journal of Biological Chemistry, 275,2000, 823-827.

[50]. B. Hilpert, H. Bohlmann, R.O.D. Camp, D. Przybyla, O. Miersch, A. Buchala and K.Apel, Isolation and characterization of signal transduction mutants of Arabidopsis thaliana that constitutively activate the octadecanoid pathway and form necrotic microlesions, Plant Journal 26, 2001,435-446.

[51]. A. Coulon, E. Berkane, A.M. Sautereau, K. Urech, P. Rouge and A. Lopez, Mode of membrane interaction of a natural cysteine-rich peptide: viscotoxin A3. BiochimicaetBiohysicaActa, 1559, 2002, 145-149. 